\title{
AUTHENTIC LEADERSHIP: SCIENTIFIC PRODUCTION ANALYSIS AND MEASUREMENT SCALES
}

\author{
BARLA L. T. PIOLI ${ }^{1}$ \\ (iD) https://orcid.org/0000-0002-0661-6151 \\ SIMONE G. FEUERSCHÜTTE ${ }^{1}$ \\ (iD) https://orcid.org/0000-0002-0963-1242 \\ RAFAEL TEZZA \\ (iD) https://orcid.org/0000-0002-6539-4608 \\ ÉVERTON L. P. L. CANCELLIER ${ }^{1}$ \\ (iD) https://orcid.org/0000-0002-2634-4763
}

To cite this paper: Pioli, B. L. T., Feuerschütte, S. G., Tezza, R., \& Cancellier, E. L. P. L. (2020). Authentic leadership: Scientific production analysis and measurement scales. Revista de Administração Mackenzie, 21(3), 1-29. doi:10.1590/1678-6971/eRAMG200126

Submission: June 16, 2019. Acceptance: Oct. 23, 2019.

Santa Catarina State University (Udesc), Florianópolis, SC, Brazil.

\section{(cc) $\mathrm{BY}$}




\section{ABSTRACT}

Purpose: This paper analyzes the publications on the "authentic leadership" construct, based on systematic literature review and bibliometric analysis techniques, and aims to identify and analyze data regarding the chronology of publications, the identification of the most prolific journals and authors, research approaches, and the existence of authentic leadership measurement/assessment tools and its applications, besides analyzing the construction of these tools.

Originality/value: Of the 431 articles analyzed, those dealing with reviews of literature do not present bibliometric data associated with the analysis of the construct measurement instruments.

Design/methodology/approach: A literature review was performed systematically, using the query "authentic leadership" on the Academic Search Premier (Ebsco), Scopus, and Web of Science databases, with no starting date delimitation, with the deadline of December 2018, which resulted in the identification of 1390 articles. After eliminating duplicates and three filters, 431 documents remained for analysis.

Findings: Three specific construct measurement/assessment tools were identified: the Authentic Leadership Questionnaire (ALQ), the Authentic Leadership Inventory (ALI), and the Authentic Leadership Integrated Questionnaire (AL-IQ). There is a predominance of quantitative studies from 2008, with a wide application of ALQ. Instruments of quantitative measurement of authentic leadership did not emerge, only tools that evidence the presence of authenticity of leaders.

\section{KEYWORDS}

Authentic leadership. Measuring scales. Construct. Authentic Leadership Questionaire. Authentic Leadership Inventory. 


\section{INTRODUCTION}

Social change has demonstrated the need to pursue a new concept of leadership, aimed at more positive relationships, like authentic leadership. Researchers associate interest in the construct due to the ethical crisis of recent decades, corruption, waste management, and declining social values, and advocate the emergence of a leadership style based on positive psychological capabilities, such as hope, confidence, optimism, and resilience (Avolio, Gardner, Walumbwa, Luthans, \& May, 2004; Cooper, Scandura, \& Schriesheim, 2005; Esper \& Cunha, 2015; Gardner \& Schermerhorn, 2004; Neider \& Schriesheim, 2011).

As a more normative, rather than descriptive, theoretical approach, authentic leadership proposes guidelines on what the leader's actions should look like and considers the importance of intersubjective relationships between leader and follower so that both can develop their skills, become aware of their weaknesses, beliefs, and values while interacting transparently, building more authentic organizations (Begley \& Stefkovich, 2007; Esper \& Cunha, 2015; Shamir \& Eilam, 2005). The focus on this approach is the authenticity of leaders and their leadership, understood as real and genuine leadership (Northouse, 2016).

This paper analyzes the publications on the "authentic leadership" construct and aims to identify and analyze data regarding the chronology of publications, the identification of the most prolific journals and authors, research approaches, and the existence of authentic leadership measurement/ assessment tools and its applications, besides analyzing the construction of these tools.

For this, the paper presents a brief theoretical foundation on authentic leadership, followed by a description of the methodology used to develop the research. Then, it presents the results obtained with the journals, according to previously established criteria, followed by the analysis of the development of the measuring instruments. It concludes with the study considerations and recommendations for future research.

\section{AUTHENTIC LEADERSHIP}

Authentic leadership emerges as a proposal to better explain how relationships between leaders and followers occur, as well as to understand the person of the leader, based on the principles of positive psychology, which include the study of positive emotions, positive traits (strengths, virtues, 
and skills), and positive institutions (democracy, family, and freedom). Positive psychology is structured around positive emotions, conceptualized by Seligman (2009, p. 374) as the "parts of a sensory system that alert us to the presence of a potential win-win situation", different from the traditional psychology, which only points out the problems to be solved and the negative emotions.

In addition, positive emotions set a mood that broadens and develops permanent social and intellectual resources, which explains, to some extent, the breadth of the authentic leaders' influence cited by Avolio et al. (2004). For the authors, this kind of leadership extends beyond organizational success, with these leaders having a larger role to play in society, addressing both public policy and social and organizational issues. Positive organizational behavior and psychological capital, constructs cited by Luthans and Avolio (2009) as constituents of the root of authentic leadership, derive from positive psychology.

Esper and Cunha (2015) point out that the theory of authentic leadership is much more a normative theory - which proposes what the actions of the leader should be like - than a descriptive theory. The authors clarify that the debate about authentic leadership in the management area arose initially among the practitioners and then gained space in the academic field. This theory is born within transformational leadership, taking on greater relevance from the special edition of the Leadership Quarterly (2005), in which the main works in the field have been published since Bass and Steidlmeier (1999), an inspiring work for the first discussions on the subject. This association of authentic leadership with transformational leadership is confirmed in studies of authentic leadership measurement tools, in which they are presented with discriminating validity of both constructs (Neider \& Schriesheim, 2011; Walumbwa, Avolio, Gardner, Wernsing, \& Peterson, 2008).

Although the authentic leadership construct has been receiving attention for over a decade, Wiewiora and Kowalkiewicz (2018) point out that a common definition of authentic leadership has not been established. Northouse (2016) draws attention to the complexity of this definition and points out that there are different definitions according to the perspective adopted: intrapersonal, interpersonal or developmental. In order to define the construct from a developmental perspective, in particular, Ilies, Morgeson, and Nahrgang (2005) and Avolio et al. (2004) consider authentic leadership as a root construct that can embody charismatic, ethical, and transformational leadership, affirming that authentic leaders act on personal values and convictions by gaining credibility, respect, and trust from their followers, encouraging different points of view, and building relationships. For Avolio et al. (2004, p. 802), authentic leaders are those "persons who 
have achieved high levels of authenticity to the extent that they know who they are, what they believe and value, and they act upon those values and beliefs while transparently interacting with others". Walumbwa et al. (2008, p. 91) add the leader's action in authentic leadership definition by stating that authentic leaders positively impact the organization and its followers:

\section{[...] when organizational leaders know and act upon their true values, beliefs, and strengths while helping others to do the same, higher levels of employees' well-being will accrue, which in turn have been shown to positively impact follower performance.}

Authentic leaders are fully aware of their behavior and therefore care about the impression they give to others, always being concerned with conveying exactly what they believe through their actions. However, the development of the concept of authentic leadership presupposes a level of self-knowledge, considered by Reed, Vidaver-Cohen, and Colwell (2011) almost unreachable, which makes leaders manage the impressions, forcing relationships increasingly transparent to achieve authenticity. This means that the desire to achieve the authentic leader's framework can lead to less ethical behavior and harsher judgments, contrary to the theory's development.

In this sense, Cooper et al. (2005) draw attention to the importance of developing measurement tools for this construct in order to be able to evaluate the results of interventions focused on its development. As a proposal, they suggest that the key dimensions of authentic leadership be identified in order to make it possible to create a theoretical basis without considering only its discrimination with other forms of leadership, which, according to the authors, can be an inconvenient practice. Still, such discrimination is presented as a resource for construct validation in the studies by Walumbwa et al. (2008) and Neider and Schriesheim (2011), which propose measurement/assessment tools for authentic leaders, such as the Authentic Leadership Questionnaire (ALQ) and the Authentic Leadership Inventory (ALI), respectively. A third scale, the Authentic Leadership Integrated Questionnaire (AL-IQ), was designed by Levesque-Côté, Fernet, Austin, and Morin (2018) the Authentic Leadership Questionnaire (ALQ with the purpose of elucidating the distinct theoretical facets of this leadership style, as well as characterizing the weaknesses and strong practices of authentic leaders. 


\section{BIBLIOGRAPHIC SURVEY METHODOLOGY}

In order to identify the current studies on the authentic leadership construct and to respond to the purposes of this research, a literature review was systematically conducted in databases of great relevance to management. According to Araújo and Alvarenga (2011), the retrospective is justified by helping to organize the knowledge already produced, allowing to find gaps and to facilitate the understanding of the explored field. The search for the articles included the Academic Search Premier (Ebsco), Scopus and Web of Science (WoS) databases, with no starting date delimitation, with the deadline of December 2018. We used the query "authentic leadership", searching the title, abstract and keywords, resulting in the identification of 1390 articles, later organized with the help of the EndNote ${ }^{\circledR}$ software and an Excel ${ }^{\circledR}$ spreadsheet. After a preliminary analysis of the publications, duplicates (481 documents) were eliminated and three filters were performed. In the first one, we removed publications that were inconsistent with the inclusion criteria of the research (publications in Portuguese, English, Spanish or Italian, which contained "authentic leadership" in the title, abstract or keywords). In the second filtering, only the documents that constituted scientific articles, published in scientific journals and freely available online in the consulted databases were considered.

The third filtering consisted of reading the articles identifying those that specifically addressed the desired theme, authentic leadership, leaving 431 documents for further analysis. Follow the process shown in Figure 3.1. 


\section{(Figure 3.1)}

\section{DESCRIPTION OF THE RESEARCH PROCESS}

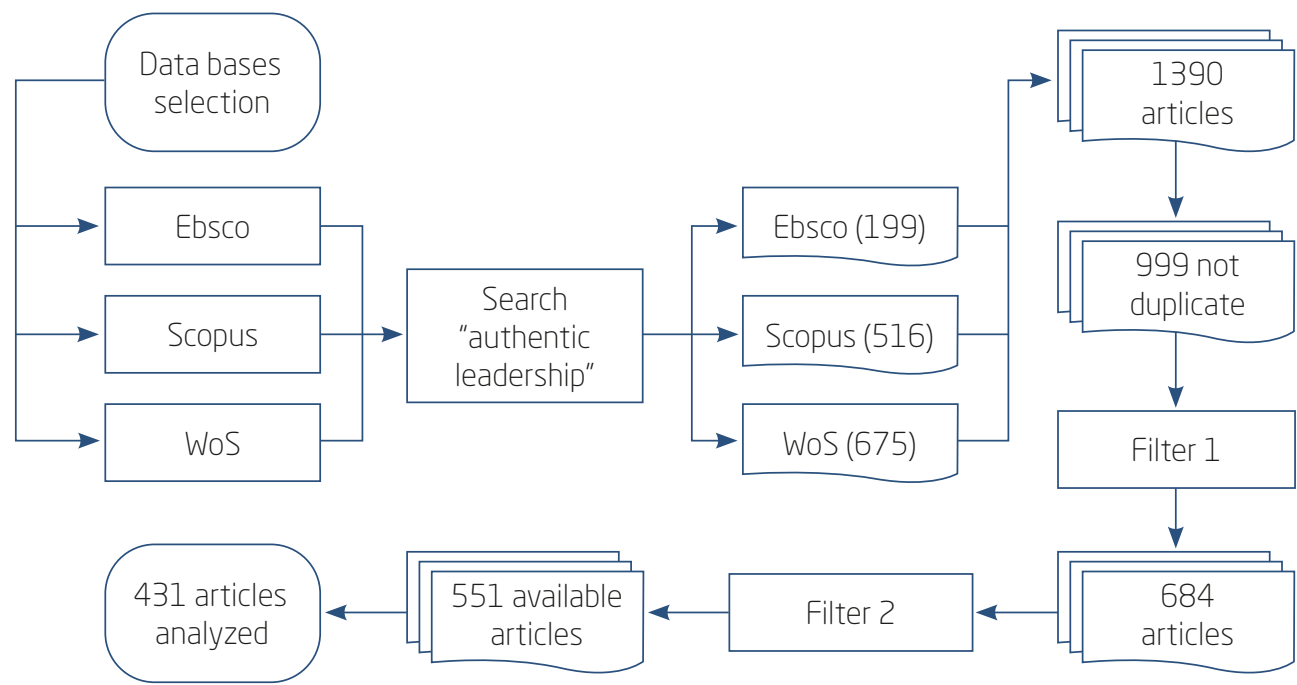

Source: Elaborated by the authors.

\section{FINDINGS}

A range of 431 articles were analyzed as: 1. chronology of publications; 2. research approach (qualitative, quantitative or mixed) and its distribution over the years; 3 . main authors; 4 . main journals; 5 . identification of measurement/assessment tools of authentic leadership and evolution of their application; and 6. analysis of the construction of these instruments.

\subsection{Chronological analysis}

The first analysis identified the evolution of publications on authentic leadership. Figure 4.1.1 shows the chronological distribution of the identified studies about the construct. 
(Figure 4.1.1)

CHRONOLOGICAL ANALYSIS OF PUBLICATIONS

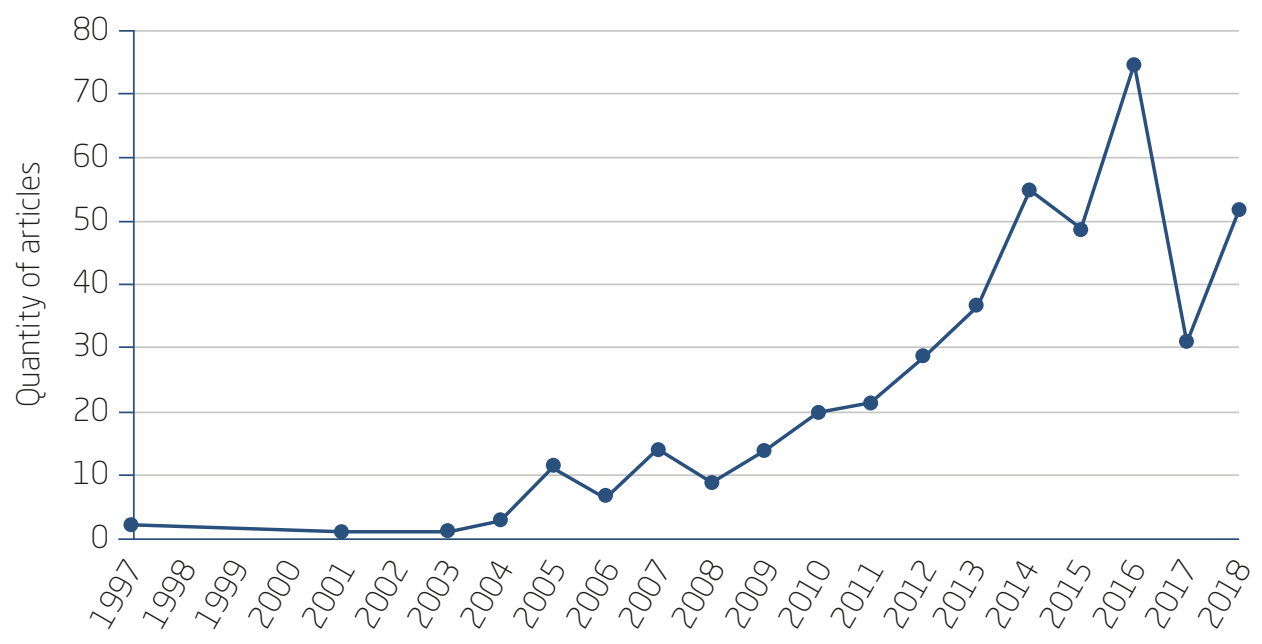

Source: Elaborated by the authors.

Cunha, Günther, Vicentini, and Esper (2015) draw attention to the fact that the authentic leadership construct first appears in Terry's (1993) book, Authentic leadership: courage in action. However, publications of articles on the subject in scientific journals appear only in 1997, with little or no expression until 2004. There is a higher frequency of publications from 2005 onwards, which can be explained by the special publication of the journal Leadership Quarterly, which helped consolidate research in the field of authentic leadership, as well as presents a better definition of the construct (Avolio \& Gardner, 2005; Esper \& Cunha, 2015). From 2013 on, the average of publications has risen to over 30 articles/year, reaching its peak in 2016, with 75 articles published in that year. The peak of publications from 2013 may be due to the spread of contemporary leadership styles, such as transformational, charismatic and ethical leadership, and the emerging need for a closer look at managing people in organizations associated with positive emotions, emotional intelligence and the individual purposes that make sense of employees' commitment to the institutions' strategic objectives (Monzani, Knoll, Giessner, Van Dick, \& Peiró, 2019).

Analyzing the decades from 1997 to 2007 and from 2008 to 2018, we had, in the first period, the publication of 39 articles and, in the second, a total of 392 articles published. While in the first decade the publication average was approximately 3.9. articles/year, in the second one, this average was ten times higher, reaching approximately 39 published articles/year. 


\subsection{Research approach}

The articles on authentic leadership were analyzed according to the research approach. In this regard, it can be observed that there is a predominance of publications with a quantitative approach $(52.5 \%)$, as shown in Figure 4.2.1.

(Figure 4.2.1)

DISTRIBUTION OF PUBLICATIONS ACCORDING TO RESEARCH APPROACH

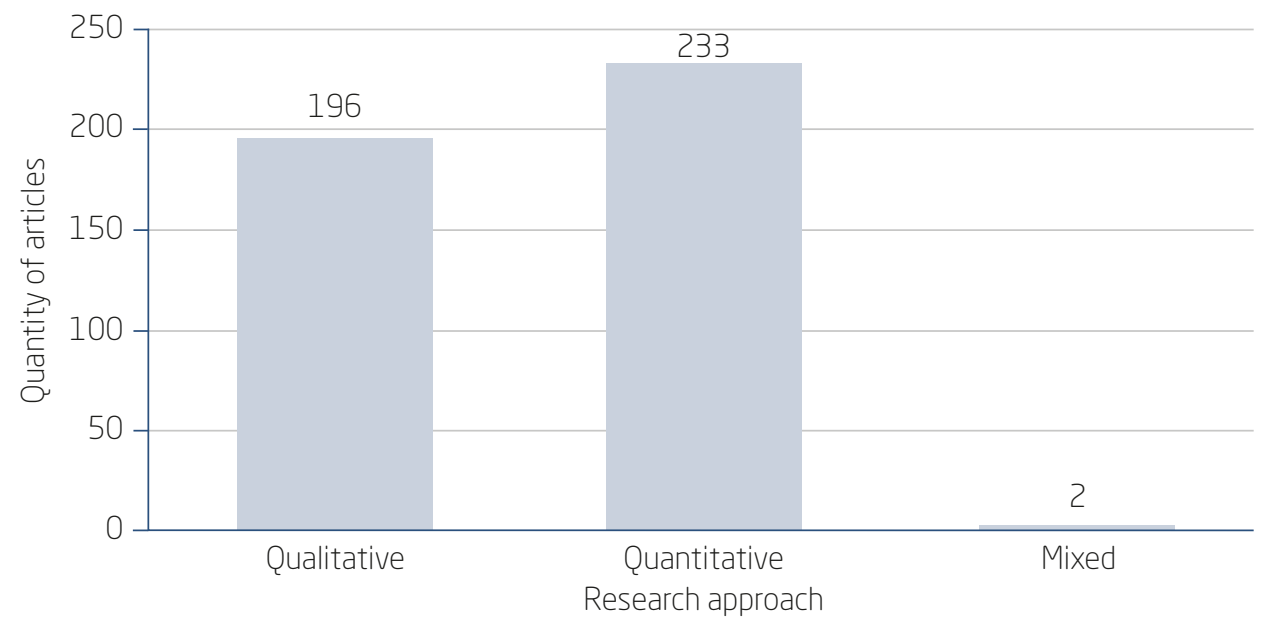

Source: Elaborated by the authors

Edmondson and McManus (2007) associate qualitative, quantitative and mixed methods with the stages of research on a particular construct. The authors classify the research as nascent, intermediate or mature, according to the adoption of qualitative, mixed and quantitative methods, respectively. In the analysis of the publications about the construct over the years (Figure 4.2.2), it is possible to observe the nascent and mature stages of research mentioned by Edmondson and McManus (2007). Although there is a clear predominance of qualitative publications at an early stage followed by an increase in quantitative studies, mixed studies are not part of this transition, appearing only in 2018 in two publications (Kong, Tsai, Tsai, Huang, \& De la Cruz, 2018; Miao, Humphrey, \& Qian, 2018). 
(Figure 4.2.2)

DISTRIBUTION OF PUBLICATIONS ACCORDING TO RESEARCH APPROACH

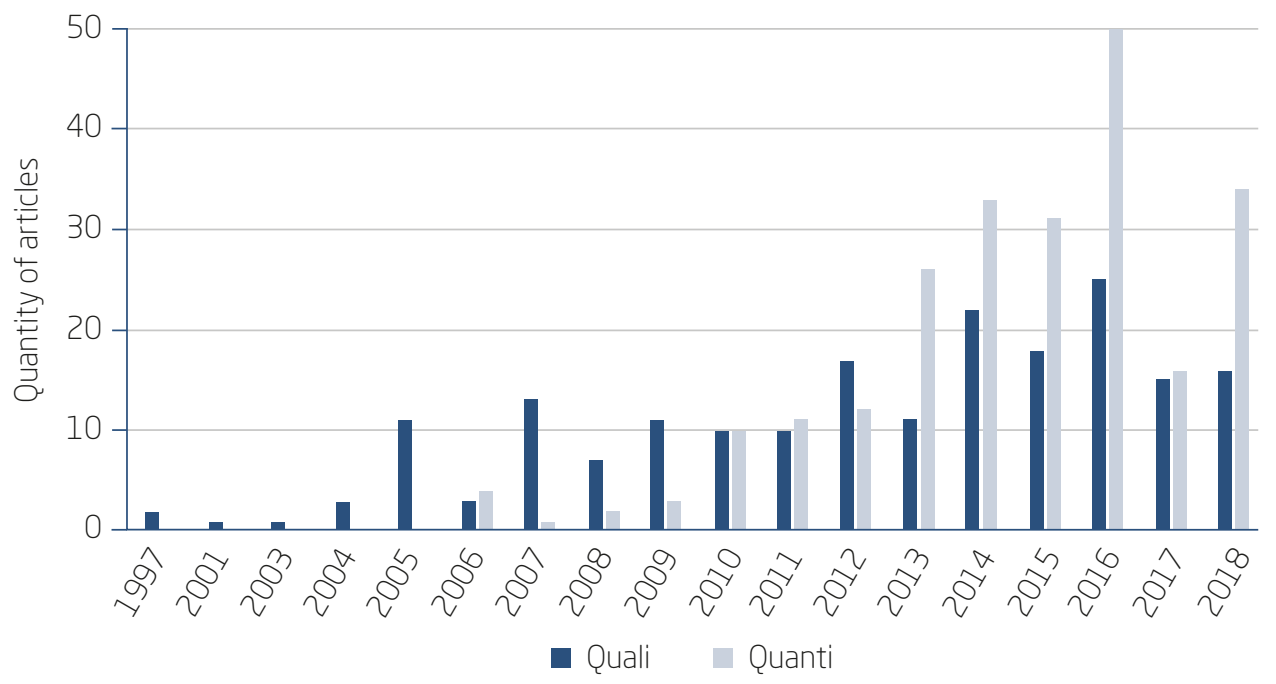

Source: Elaborated by the authors.

The increase of quantitative publications in 2008 is justified by the preparation, in that year, of the ALQ by Walumbwa et al. (2008), which was the first construct measurement instrument based on a 16-item scale constructed from the multidimensional framework proposed by Ilies et al. (2005). In 2011, intending to improve the ALQ and proposing the creation of an open access instrument for researchers with quantitative content validity, Neider and Schriesheim (2011) developed the ALI.

\subsection{Authorship distribution}

Cunha et al. (2015) identified in their study that a large number of citations correspond to a small group of authors, which is similar to Lotka's (1926) experiment, which states that a limited number of researchers produce much about a given area of knowledge, while $60 \%$ of authors produce only one study. The authors of the publications can be counted in three different ways: direct counting - considering only the first-named author; the complete count - at which all authors are considered; and the adjusted score - each author receiving a share of contribution for the publication (with two authors, both receiving $50 \%$ of the credit). 
Authors such as Nath and Jackson (1991) point out that there are no essential differences between counts and recommend direct counting. That said and considering the unfeasibility of complete and adjusted counts in this sample of 431 articles, we opted for direct counting. Figure 4.3.1 presents the distribution of authors by production.

\section{(Figure 4.3.1)}

\section{DISTRIBUTION OF AUTHORS BY PRODUCTION}

\begin{tabular}{ccccccccc}
\hline Production & 1 & 2 & 3 & 4 & 5 & 6 & 7 & Total \\
\hline Authors & 312 & 27 & 9 & 6 & 1 & 0 & 1 & 356 \\
\hline
\end{tabular}

Source: Elaborated by the authors.

According to these data, 312 authors produced only one article related to authentic leadership, representing $73 \%$ of the total number of authors who published on the subject in the analyzed period, which indicates a high number of poor authors and corroborates Lotka's Law. Figure 4.3.2 presents the authors who were indicated as the main authors in more than three publications.

(Figure 4.3.2)

MOST PRODUCTIVE AUTHORS IN THE ANALYZED PERIOD

\begin{tabular}{lc}
\multicolumn{1}{c}{ Author } & Production \\
\hline Heather K. Spence Laschinger & 7 \\
\hline Tony Fusco & 5 \\
\hline Lucas Monzani & 4 \\
\hline Morten Birkeland Nielsen & 4 \\
\hline Arménio Rego & 4 \\
\hline Orly Shapira-Lishchinsky & 4 \\
\hline Fred O. Walumbwa & 4 \\
\hline Carol A. Wong & 4 \\
\hline
\end{tabular}

Source: Elaborated by the authors.

Considering the direct counting performed in this research, Heather K. Spence Laschinger was the lead author of seven articles, followed by Tony Fusco with lead authorship in five articles. Both authors worked in 
partnership with the publications of their research. Even the partnership of authors is recurrent when we look at publications on the authentic leadership construct. Of the 431 articles identified, 338 of them have two or more authors, in $31 \%$ of them only two authors participate and $24 \%$ are published with three authors.

\subsection{Most relevant journals}

Under the Bradford Law, there is a regular distribution of publications in academic journals in a particular area of knowledge. Few journals tend to concentrate most publications while many journals publish few articles on the subject (OLUIĆ-VUKOVIĆ, 1997). Bogaert, Rousseau, and Van Hecke (2000) justify this distribution considering that the initial articles of a certain subject are submitted to a restricted number of journals, the more articles are accepted for publication in this journal, the greater the probability of another article of the same theme joining them to create a nucleus of publications with superior quality and relevance in the area.

Applying the Bradford Law, three zones were obtained. The first one contains a small number of highly productive journals $(3 \%$ of all journals concentrate $24 \%$ of the articles), the second contains a larger number of journals, but with lower productivity, while the third zone concentrates a large number of poorly productive journals ( $78 \%$ of total journals with only one article published). Figure 4.4.1 shows the three zones and their journals, which compound zones 1 and 2 . The journals of zone 3 are not represented, due to their large volume and low relevance.

(Figure 4.4.1)

PRODUCTIVITY OF THE JOURNALS ANALYZED

Zone 1

Corresponds to $3 \%$ of total journals.

Corresponds to $24 \%$ of total articles.

The Leadership Quarterly (28)

Leadership and Organization Development Journal (24)

Journal of Business Ethics (16)

Journal of Leadership and Organizational Studies (13)

Educational Management Administration \& Leadership (11)

Journal of Nursing Management (10) 


\section{(Figure 4.4.1 (continuation)) \\ PRODUCTIVITY OF THE JOURNALS ANALYZED}

\section{Zone 2}

Corresponds to $19 \%$ of total journals.

Corresponds to 33\% of total articles.

Journal of Nursing Administration (7)

Leadership (7)

Social Behavior and Personality (6)

Journal of Leadership Studies (6)

European Journal of Work and Organizational Psychology (5)

SA Journal of Human Resource Management (5)

He Kupu (4)

International Coaching Psychology Review (4)

International Journal of Nursing Studies (4)

Journal of Management (4)

Psicothema (4)

Safety Science (4)

Sustainability (4)

Journal of Educational Administration (4)

Journal of Organizational Behavior (4)

Journal of Management Development (4)

Adult Learning (3)

Coaching Psychologist (3)

European Journal of Training and Development (3)

Zone 2

Journal of Advanced Nursing (3)

Journal of Construction Engineering \& Management (3)

Organizational Dynamics (3)

AACN Advanced Critical Care (2)

Burnout Research (2)

Consulting Psychology Journal (2)

Current Psychology (2)

Development and Learning in Organisations (2) 


\section{(figure 4.4.1 (conclusion))}

PRODUCTIVITY OF THE JOURNALS ANALYZED

\begin{tabular}{l}
\hline Frontiers in Psychology (2) \\
\hline Harvard Business Review (2) \\
\hline Human Resource Management (2) \\
\hline Human Resource Management Review (2) \\
\hline International Journal for Quality Research (2) \\
\hline International Journal of Applied Business and Economic Research (2) \\
\hline International Journal of Leadership in Education (2) \\
\hline International Journal of Productivity and Performance Management (2) \\
\hline International Journal of Project Management (2) \\
\hline Journal of Business Research (2) \\
\hline Journal of Managerial Psychology (2) \\
\hline Journal of Occupational and Organizational Psychology (2) \\
\hline Journal of Psychology in Africa (2) \\
\hline Management in Education (2) \\
\hline Management Learning (2) \\
\hline Management Research Review (2) \\
\hline Personnel Review (2) \\
\hline Sorresponologist-Manager Journal (2) \\
\hline Corresponds to 43\% of total articles.
\end{tabular}

Source: Elaborated by the authors.

Six journals have been identified as most relevant in authentic leadership publications. The Leadership Quarterly, first in the list, concentrates 28 articles. The greater likelihood that articles will be attracted to this journal is justified by the publication, in 2005, of a special edition on the subject that is considered a milestone for the consolidation of research of the subject in the field. To prove the degree of relevance of the journals, their relevance was investigated from three forms of classification. The first one, used in Brazil and called Qualis-Periódicos, is a system used to classify the scientific production of graduate programs in relation to articles published 
in scientific journals and annals of events. The second, called the Impact Factor, is calculated annually by the Institute for Scientific Information/ Thompson Scientific Reuters and published by the Journal Citations Reports (JCR), and it compares and evaluates journals by citation accumulation and tabulation. The SCImago Journal \& Country Rank (SJR) was the third form of classification investigated here and consists of the evaluation of the journal's scientific prestige based on the idea that a journal's area of knowledge, quality, and reputation directly influence its citations carried out (González-Pereira, Guerrero-Bote, \& Moya-Anegón, 2010; Jacsò, 2010; Moed, 2010). Figure 4.4.2 gives the rating data mentioned and confirms the relevance mainly of The Leadership Quarterly.

(Figure 4.4.2)

RELEVANCE OF ANALYZED JOURNALS

\begin{tabular}{lcccc}
\hline \multicolumn{1}{c}{ Journals } & $\begin{array}{c}\text { Qualis } \\
\text { 2013-2016 }\end{array}$ & JCR 2018 & SJR 2018 \\
\hline The Leadership Quarterly (28) & $\mathrm{Al}$ & 5.631 & 3.19 \\
\hline Leadership and Organization Development Journal (24) & - & 1.462 & 0.52 \\
\hline Journal of Business Ethics (16) & $\mathrm{A} 1$ & 3.796 & 1.86 \\
\hline Journal of Leadership and Organizational Studies (13) & $\mathrm{A} 2$ & 1.597 & 0.85 \\
\hline Educational Management Administration \& Leadership (11) & - & 1.804 & 1.37 \\
\hline Journal of Nursing Management (10) & $\mathrm{Al}$ & 2.386 & 1.07 \\
\hline
\end{tabular}

Source: Elaborated by the authors.

\subsection{Identification of measurement/evaluation instruments of the authentic leadership construct}

According to the analysis recommended by Edmondson and McManus (2007), considering the mature stage of authentic leadership research, 233 articles using quantitative research techniques were identified. Among these articles, some authentic leadership measurement/assessment tools are highlighted.

Walumbwa et al. (2008), based on the multidimensional theoretical model of analysis of authentic leadership proposed by Ilies et al. (2005), developed the ALQ. It is an instrument based on 16 items and composed of four dimensions of leader behavior: self-awareness, relational transparency, balanced processing, and internalized moral perspective. The study by Walumbwa et al. (2008) proposes to validate a quantitative tool for assessing 
authentic leadership and investigating its discriminant validity against two other scales: the Multifactor Leadership Questionnaire (MLQ) (Bass \& Avolio, 2000) and the Transformational Leadership Questionnaire (TLI) (Podsakoff, MacKenzie, Moorman, \& Fetter, 1990).

Due to its commercial nature, ALQ is not freely available for researchers to use it in their research. Therefore, with the objective of creating a free access tool for researchers that has quantitative content validity, as well as evaluating the items that compose the ALQ quantitatively through analysis of variance (Anova) and factor analysis (EFA and CFA), Neider and Schriesheim (2011) developed the ALI. This new tool takes, as its starting point, the items available in ALQ and adds others, as judged by the authors, for subsequent statistical tests. Both studies, for the creation of ALQ and ALI, conducted subsequent tests for the reliability of internal consistency and construct validity verified by the instruments, compared with other leadership styles, such as transformational leadership and ethical leadership.

Although both scales have been widely used, Levesque-Côté et al. (2018) propose the elaboration of a new instrument that, justify the authors, can faithfully capture the multidimensionality of the authentic leadership construct, the AL-IQ. This new instrument is based on the previous ones (ALQ and ALI). However, it uses the combination of confirmatory factor analyses (CFA) and an exploratory structural equation modeling (Esem) to evaluate the construct validity (factorial structure, reliability, and validity related to the criterion). These authors highlight, as the main contribution of this new instrument, the fact that it is an optimized alternative to elucidate the different theoretical facets of this style of leadership, besides characterizing the weaknesses and strengths of the practices of leaders considered authentic. According to them, in both ALQ and ALI there is an excessive overlap of items, which indicates that there is an overlap of the dimensions of authentic leadership, impairing their correct verification. Nevertheless, although the authors' intention is to contribute to the distinct capture of data that can elucidate the four dimensions of authentic leadership, no studies were found that applied this scale and empirically demonstrate their results.

Figure 4.5.1 shows the chronological distribution of publications regarding the application of authentic leadership measurement/assessment scales, the ALQ and the ALI. 


\section{(Figure 4.5.1)}

DISTRIBUTION OF PUBLICATIONS ACCORDING TO THE APPLICATION OF AUTHENTIC LEADERSHIP MEASUREMENT/EVALUATION TOOLS

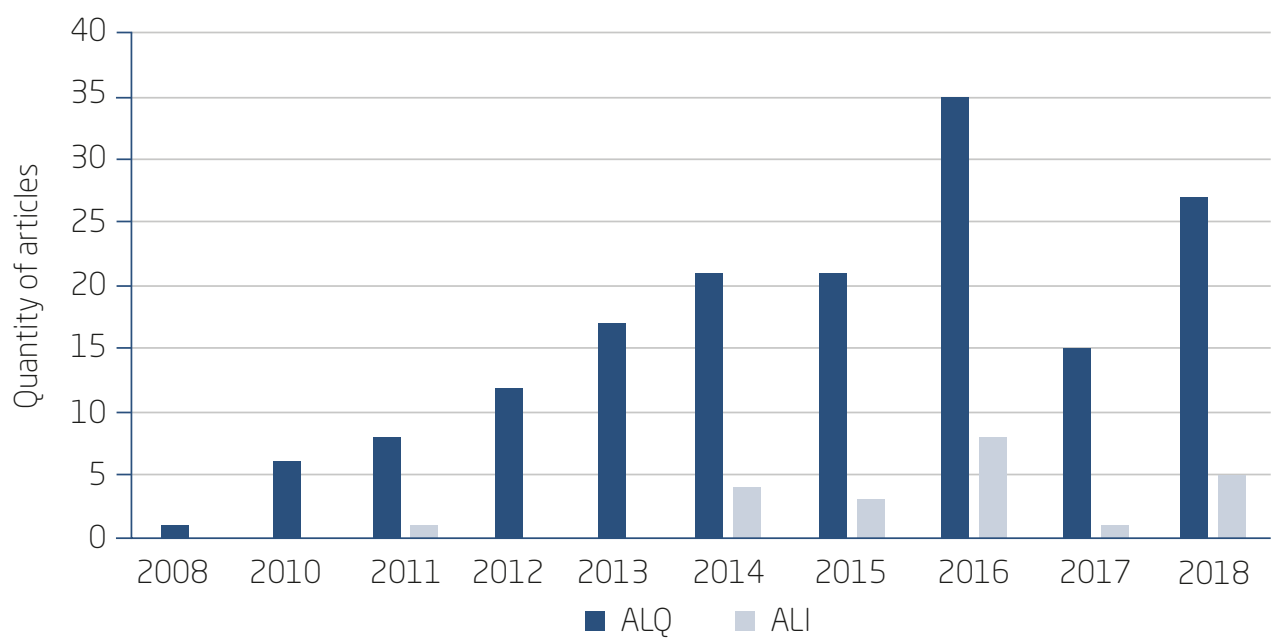

Source: Elaborated by the authors

Studies with the application of ALQ were predominant in the research $(88,1 \%)$, which may justify its emergence prior to ALI, and ALQ being the basis of ALI. Many authors justify choosing the ALQ due to its applicability, previous publications and the consolidation of the tool (Erkutlu \& Chafra, 2013; Hystad, Bartone, \& Eid, 2013; Yagil \& Medler-Liraz, 2014; Carvalho, Cunha, Balsanelli, \& Bernardes, 2016; Monzani, Braun, \& Van Dick, 2016; Rautenbach \& Rothmann, 2017; Oh, Cho, \& Lim, 2018).

Still, some quantitative studies were found that do not apply the mentioned scales and aim to measure leadership from various instruments such as Authenticity Inventory - AI:3 (Kernis \& Goldman, 2005; Toor \& Ofori, 2009), Leadership Behavioral Inventory - LBI (Kotzé \& Venter, 2010; Spangenberg \& Theron, 2002), the Executive Servant Leadership Scale ESLS (Reed et al., 2011), the Identity Leadership Inventory - ILI (Steffens et al., 2014), Kunja Leadership (Ryu, 2015), the Servant Leadership Survey - SLS (Van Dierendonck, 2011; Coetzer, Bussin, \& Geldenhuys, 2017), in addition to the model proposed by Schaufeli and Bakker (2004), used by Mubarak and Noor (2018). However, neither aims to measure/assess authentic leadership in the way the ALQ and ALI were constituted. 


\subsection{Construction analysis of measurement/assessment instruments of authentic leadership construct}

To generate knowledge, certain phenomena require observations and quantifications of variables. However, the use of weak measurement strategies on the grounds of unfamiliarity with methods for developing reliable and valid instruments can lead researchers to misleading measurements. In order to clarify the steps for the construction of variable measurement instruments, DeVellis (2012) presents five steps that should be followed in the development of a scale to present reliable measurement results, which have been applied by several authors (El Akremi, Gond, Swaen, De Roeck, \& Igalens, 2015; Raja \& Agrawal, 2017; Strese, Gebhard, Feierabend, \& Brette, 2018). Following these orientations of DeVellis (2012) as guidelines in the development of reliable measurement instruments, the instruments of measurement/assessment of authentic leadership of expressive application in quantitative studies on the subject were analyzed.

Initially, the researcher should be clear about what to measure, whether to measure a specific or generic construct and whether this construct is different from others already measured. The next step refers to the generation of measurement scale items that will represent the latent trace. This step should be done exhaustively based on both the literature and the researcher's creativity. Regarding the generation of the items, for the construction of the ALQ, 35 items were generated from an extensive literature review, by deductive and inductive approaches, thesis and dissertation analyses on the theme and from discussions with leadership research groups. After validation by a group of Ph.D. students with experience in research on the subject, the analysis of the items was performed according to the multidimensional model of Ilies et al. (2005); 19 items were eliminated, leaving 16 items. For the generation of ALI items, the researchers started from the ALQ sample provided by the authors and developed two other items for each dimension proposed in the development of this scale. In both instruments, the measurement format was a 5-point scale; however, for ALQ, a frequency scale was used, while for ALI, a rating scale was used.

The next step refers to the review of the generated items. This review should be performed by experts in the field of application of the study and includes the evaluation of the clarity, objectivity, and relevance of the items. Still, regarding the scale items, DeVellis (2012) points out that the experts' suggestion should be considered about the inclusion of validation items related to other scales, whose purpose is to evaluate the validity of the 
construct measurement items. Review of initial items by subject experts for the construction of ALQ was undertaken by undergraduate and graduate students with experience in leadership studies at the University of NebraskaLincoln and the Arizona State University School of Global Management and Leadership, not contemplating, at this stage, the studies of quantitative analysis in order to eliminate the subjectivity inherent in the process. In the development of the ALI, this evaluation stage with experts did not occur. However, quantitative content validity tests, Anova, and t-test were performed in order to contribute to the quantitative validation of the items.

Pre-testing characterizes the next step. They should be performed with individuals who have characteristics similar to those of the population to be researched and aim to adapt the assessment instrument, measure the time to complete the instrument by respondents and make adjustments to the items in relation to their semantics. However, in both surveys, there was no pre-test of the instruments.

The next step is the evaluation of these items through statistical analysis (correlation, construct reliability analysis, factor analysis) and the scale revision and adjustments in its extension. In the studies presented for the development of the scales, the samples obtained in the ALQ and ALI applications are considered satisfactory for the performed analyzes. Initially, for the validation of the instrument, an American sample (224 respondents) and a Chinese sample (212 respondents) were considered. With these samples, the following analyzes were performed: exploratory factorial (EFA) and confirmatory factorial (CFA). With EFA, the researchers intended to confirm the inclusion of items in each of the dimensions theoretically proposed by Ilies et al. (2005), and with CFA, the proposal was to build a structural equation model for the construct of authentic leadership. After these steps, there was no change in the items initially proposed.

In the development of ALI, the proposal was to eliminate subjective judgments about the attribution of items to each of the dimensions by performing statistical tests. Anova and t-test were performed to check if the items were correctly attributed to each of the dimensions proposed in the ALQ and then to eliminate subjective judgments in the initial proposition for the instrument. After the analyses performed in the development of ALI, Neider and Schriesheim (2011) suggest content evaluation for ALQ and consider the elimination of two items in order to optimize the final instrument, thus creating the ALI.

Both instruments were developed considering the multidimensionality of the construct previously presented by Ilies et al. (2005). The leader's four 
dimensions of behavior: self-awareness, relational transparency, balanced processing, and internalized moral perspective were confirmed by CFA and EFA by Walumbwa et al. (2008). The number of items for the ALQ was 16, as initially proposed and, in the development of the ALI, the final instrument included 14 items.

For the development of AL-IQ, recently developed, Levesque-Côté et al. (2018) grouped the items that constitute ALQ and ALI using a classic method of cross-cultural adaptation since these tools were not available in the French language. The AL-IQ instrument ended with 30 items and the focus of the analyses of this instrument was the confirmatory factor analysis (CFA) and the Esem in order to confirm the multidimensionality of the tool. However, the initial steps, such as item generation, measurement format, expert review of items and inclusion of validation items were obtained by using the items in the scales already in use (ALQ and ALI) and the final tests in order to optimize the scale size were not performed.

Figure 4.6.1 presents this schematic analysis of the process of constructing authentic leadership measurement/assessment instruments compared to the guidelines proposed by DeVellis (2012).

\section{(Figure 4.6.1) \\ ANALYSIS OF AUTHENTIC LEADERSHIP CONSTRUCT MEASUREMENT/ASSESSMENT TOOLS FROM THE GUIDELINES PROPOSED BY DEVELLIS (2012)}

\begin{tabular}{|c|c|c|c|}
\hline Guidelines in scale development by DeVellis (2012) & ALQ (2008) & ALI (2011) & AL-IQ (2018) \\
\hline 1. Determine what to measure & $\nabla$ & $\nabla$ & $\nabla$ \\
\hline 2. Generate an item pool & $\nabla$ & $\nabla$ & $x$ \\
\hline 3. Determine the format for measurement & $\square$ & $\square$ & $x$ \\
\hline 4. Have initial item pool reviewed by experts & $\nabla$ & $x$ & $x$ \\
\hline 5. Consider the inclusion of validation items & $x$ & $x$ & $x$ \\
\hline 6. Administer items to a development sample & $x$ & $x$ & $\nabla$ \\
\hline 7. Evaluate the items & $x$ & $\square$ & $\nabla$ \\
\hline 8. Optimize scale length & $x$ & $\nabla$ & $x$ \\
\hline
\end{tabular}

Source: Elaborated by the authors. 
Among the objectives associated with the application of authentic leadership measurement/assessment tools, we found: engagement-related ALQ applications (Giallonardo, Wong, \& Iwasiw, 2010; McAuliffe, Bostain, \& Witchel, 2019), work team performance relation (Hannah, Avolio, \& Walumbwa, 2011), development of the psychological capital and creativity of followers of authentic leaders (Rego, Sousa, Marques, \& Cunha, 2012), job satisfaction (Leigh, 2014), and organizational identity relation (Monzani et al., 2016). Also associated with authentic leaders are a collaboration between health professionals (Regan, Laschinger, \& Wong, 2016), perception of organizational justice (Kampa, Rigotti, \& Otto, 2017) and innovation in higher education (Elrehail, Emeagwali, \& Abdallah, 2018). In addition to the studies presented, there were also proposals for validating the ALQ for different populations (Xiong \& Fang, 2014; Moriano, Molero, \& Mangin, 2011; Cervo, Mónico, Santos, \& Hutz, 2016). Considering criticisms that arose after the publication of the ALQ in 2008, Avolio, Wernsing, and Gardner (2018) proposed a review on instrument development and validation. This review considers component testing and applies a higher-order model (HOM) to recent survey data.

With regard to ALI applications, the goals associated with job satisfaction (Cerne, Dimovski, Maric, Penger, \& Skerlavaj, 2014), engagement, optimism and confidence (Stander, Beer, \& Stander, 2013), innovation (Jam, Kaur, \& Kwee, 2016), transparency of organizational communication (Jiang \& Men, 2017), and organizational effectiveness (Lee, 2018) can be highlighted.

\section{CONCLUSIONS AND RECOMMENDATIONS}

Seeking to help in the organization of the knowledge already produced about authentic leadership, 431 articles were analyzed regarding the chronological distribution, research approaches, main authors and journals, and the identification and analysis of the construction of the measurement/ assessment tools of the construct.

Authentic leadership publications have grown rapidly since 2013, as a result of the spread of contemporary leadership styles and the emerging need for a closer look at people management in organizations. The Leadership Quarterly was identified as the most relevant journal after the application of the Bradford Law, a fact confirmed by the analysis of other indicators of the relevance of publications (Qualis-Periódicos, JCR and SJR). The study of the theme is in the mature stage and quantitative researches, expressive 
from the creation of the ALQ in 2008, represent $54,5 \%$ of the total studies analyzed. Three instruments for measuring/assessing the authentic leadership construct (ALQ, ALI, and AL-IQ) were identified, with the ALQ being the most applicable instrument (70\% of quantitative studies).

As for the analysis of the construction of authentic leadership measurement/assessment instruments according to the guidelines proposed by DeVellis (2012), all were clearly prepared for the measure, but there are still improvements to be made in all the analyzed instruments in order to make them more reliable. Psychometric validation of the ALQ is suggested in order to correct possible deviations evidenced by the statistical tests presented in the development of the ALI, as well as a new general assessment of the instrument, reconsidering the six initial items excluded from the analysis. The proposal is to investigate, by performing an EFA followed by a CFA, whether these items could not generate a new dimension beyond those proposed by Ilies et al. (2005) in their multidimensional theoretical model. Referring to the AL-IQ, it is evident the need to apply the instrument in other populations to validate and consolidate the tool, as well as to conduct studies in English-speaking populations in order to verify the inter-linguistic validity of the items.

In all the studies analyzed, no instruments for the quantitative measurement of authentic leadership have emerged, although the research is in its mature stage and several associations with other theories have been identified. What the authors present are tools that show the leader's authenticity, but they fail to determine how much one leader is more authentic than another. As a limitation of this investigation, the issue of access to data and paid articles stands out, which reduces the scope of the study to the analysis of free articles.

\section{)}

\section{ACKNOWLEDGEMENTS}

Thanks to Coordination for the Improvement of Higher Education Personnel (Coordenação de Aperfeiçoamento de Pessoal de Nível Superior Capes), to the Research Support Foundation of the State of Santa Catarina (Fundação de Amparo à Pesquisa do Estado de Santa Catarina - Fapesc), through the Research Support Program (PAP/Fapesc/Udesc), and to the Santa Catarina State University (Udesc) for the financial aid received in the form of a scholarship at the doctoral level through the Graduate Monitoring Scholarship Program (Programa de Bolsas de Monitoria de Pós-Graduação - Promop). 


\section{LIDERANÇA AUTÊNTICA: ANÁLISE DA PRODUÇÃO CIENTÍFICA E DE ESCALAS DE MENSURAÇÃO}

\section{RESUMO}

Objetivo: Este artigo desenvolve uma análise das publicações sobre o construto "liderança autêntica" a partir de técnicas de revisão sistemática de literatura e análise bibliométrica, e tem como propósitos identificar e analisar dados referentes à cronologia das publicações, à identificação dos periódicos e autores mais prolíferos sobre o tema, às abordagens de pesquisa, à existência de instrumentos de mensuração/avaliação desse construto e de suas aplicações, além de analisar a construção desses instrumentos.

Originalidade/valor: Dos 431 artigos analisados, aqueles que tratam de revisões de literatura não apresentam dados bibliométricos associados à análise dos instrumentos de mensuração do construto.

Design/metodologia/abordagem: Realizou-se uma revisão de literatura de forma sistemática utilizando a query "authentic leadership" nas bases de dados Academic Search Premier (Ebsco), Scopus e Web of Science, sem delimitação de data para início, com o limite temporal de dezembro de 2018, e identificaram-se 1.390 artigos. Depois da eliminação dos artigos duplicados e após três filtragens, restaram 431 documentos para análise. Resultados: Identificaram-se três escalas que tratam especificamente de mensuração/avaliação do construto liderança autêntica: Authentic Leadership Questionaire (ALQ), Authentic Leadership Inventory (ALI) e Authentic Leadership Integrated Questionnaire (AL-IQ). Há uma predominância dos estudos quantitativos a partir de 2008, com ampla aplicação do ALQ, já que essa é a ferramenta-base para as demais escalas. Contudo, não foram identificados instrumentos de mensuração quantitativa da liderança autêntica, apenas ferramentas que evidenciam a presença de autenticidade dos líderes.

\section{PALAVRAS-CHAVE}

Liderança autêntica. Escalas de mensuração. Construto. Authentic Leadership Questionaire. Authentic Leadership Inventory. 


\section{REFERENCES}

Araújo, R. F., \& Alvarenga, L. (2011). A bibliometria na pesquisa científica da pós-graduação brasileira de 1987 a 2007. Revista Eletrônica de Biblioteconomia e Ciência da Informação, 16(31), 51-70.

Avolio, B. J., \& Gardner, W. L. (2005). Authentic leadership development: Getting to the root of positive forms of leadership. Leadership Quarterly, 16(3), 315-338.

Avolio, B. J., Gardner, W. L., Walumbwa, F. O., Luthans, F., \& May, D. R. (2004). Unlocking the mask: A look at the process by which authentic leaders impact follower attitudes and behaviors. The Leadership Quarterly, $15,801-823$.

Avolio, B. J., Wernsing, T., \& Gardner, W. L. (2018). Revisiting the development and validation of the authentic leadership questionnaire: Analytical clarifications. Journal of Management, 44(2), 399-411.

Bass, B. M., \& Avolio, B. J. (2000). MLQ: Multifactor leadership questionnaire (2nd ed.). Redwood City: Mind Garden.

Bass, B. M., \& Steidlmeier, P. (1999). Ethics, character and authentic transformational leadership behavior. Leadership Quarterly, 10(2), 181-217.

Begley, P. T., \& Stefkovich, J. (2007). Integrating values and ethics into post secondary teaching for leadership development: Principles, concepts, and strategies. Journal of Educational Administration, 45(4), 398-412.

Bogaert, J., Rousseau, R., \& Van Hecke, P. (2000). Percolation as a model for informetric distributions: Fragment size distribution characterised by Bradford curves. Scientometrics, 47(2), 195-206.

Carvalho, A. G. F., Cunha, I. C. K. O., Balsanelli, A. P., \& Bernardes, A. (2016). Liderança autêntica e perfil pessoal e profissional de enfermeiros. Acta Paulista de Enfermagem, 29(6), 618-625.

Cerne, M., Dimovski, V., Maric, M., Penger, S., \& Skerlavaj, M. (2014). Congruence of leader selfperceptions and follower perceptions of authentic leadership: Understanding what authentic leadership is and how it enhances employees' job satisfaction. Australian Journal of Management, 39(3), 453-471.

Cervo, C. S., Mónico, L. S. M., Santos, N. R., \& Hutz, C. S. (2016). Authentic Leadership Questionnaire: Invariance between samples of Brazilian and Portuguese employees. Psicologia: Reflexão e Crítica, 29(1), 40-51. 
Coetzer, M. F., Bussin, M. H. R., \& Geldenhuys, M. (2017). Servant leadership and work-related well-being in a construction company. SA Journal of Industrial Psychology, 43(1), 1-10.

Cooper, C. D., Scandura, T. A., \& Schriesheim, C. A. (2005). Looking forward but learning from our past: Potential challenges to developing authentic leadership theory and authentic leaders. The Leadership Quarterly, 16(3), 475-493.

Cunha, C. J. C. de A., Günther, H. F., Vicentini, L. C., \& Esper, A. (2015). Liderança autêntica: Um estudo bibliométrico. Espacios, 36(1), 7-24.

DeVellis, R. F. (2012). Scale development: Theory and application (3rd ed.). Beverly Hills: Sage.

Edmondson, A. C., \& McManus, S. E. (2007). Methodological fit in management field research. Academy of Management Review, 32 (4), 1246-1264.

El Akremi, A., Gond, J. P., Swaen, V., De Roeck, K., \& Igalens, J. (2018). How do employees perceive corporate responsibility? Development and validation of a multidimensional corporate stakeholder responsibility scale. Journal of Management, 44(2), 619-657.

Elrehail, H., Emeagwali, O. L., \& Abdallah, A. (2018). The impact of transformational and authentic leadership on innovation in higher education: The contingent role of knowledge sharing. Telematics and Informatics, 35(1), 55-67.

Erkutlu, H., \& Chafra, J. (2013). Effects of trust and psychological contract violation on authentic leadership and organizational deviance. Management Research Review, 36(9), 828-848.

Esper, A. J. F., \& Cunha, C. J. C. A. (2015). Liderança autêntica: Uma revisão integrativa. Navus, 5(2), 60-72.

Gardner, W. L., \& Schermerhorn, J. R. (2004). Unleashing individual potential: Performance gains through positive organizational behavior and authentic leadership. Organizational Dynamics, 33(3), 270-281.

Giallonardo, L. M., Wong, C. A., \& Iwasiw, C. L. (2010). Authentic leadership of preceptors: Predictor of new graduate nurses' work engagement and job satisfaction. Journal of Nursing Management, 18(18), 993-1003.

González-Pereira, B., Guerrero-Bote, V. P., \& Moya-Anegón, F. (2010). A new approach to the metric of journals' scientific prestige: The SJR indicator. Journal of Informetrics, 4(3), 379-391.

Hannah, S. T., Avolio, B. J., \& Walumbwa, F. O. (2011). Relationships between authentic leadership, moral courage, and ethical and pro-social behaviors. Business Ethics Quarterly, 21 (4), 555-578. 
Hystad, S. W., Bartone, P. T., \& Eid, J. (2013). Positive organizational behavior and safety in the offshore oil industry: Exploring the determinants of positive safety climate. The Journal of Positive Psychology, 9(1), 42-53.

Ilies, R., Morgeson, F. P., \& Nahrgang, J. D. (2005). Authentic leadership and eudaemonic well-being: Understanding leader-follower outcomes. The Leadership Quarterly, 16(3), 373-394.

Jacsó, P. (2010). Comparison of journal impact rankings in the SCImago Journal \& Country Rank and the Journal Citation Reports databases. Online Information Review, 34(4), 642-657.

Jam, F. A., Kaur, S., \& Kwee, N. B. (2016). Interactive effects of gender and leadership styles on open service innovation: A study of Malaysian doctors. International Journal of Environmental Research, 13(3), 1287-1304.

Jiang, H., \& Men, R. L. (2017). Creating an engaged workforce: The impact of authentic leadership, transparent organizational communication, and work-life enrichment. Communication Research, 44(2), 225-243.

Kampa, J., Rigotti, T., \& Otto, K. (2017). Mechanisms linking authentic leadership to emotional exhaustion: The role of procedural justice and emotional demands in a moderated mediation approach. Industrial Health, 55(2), 95-107.

Kernis, M. H., \& Goldman, B. M. (2005). From thought and experience to behavior and interpersonal relationships: A multicomponent conceptualization of authenticity. In A. Tesser, J. V. Wood, \& D. A. Stapel (Eds.). On building, defending and regulating the self: A psychological perspective (pp. 31-52). New York: Psychology Press.

Kong, F., Tsai, C.-H., Tsai, F.-S., Huang, W., \& De la Cruz, S. M. (2018). Psychological capital research: A meta-analysis and implications for management sustainability. Sustainability, 10(10), 3457-3466.

Kotzé, M., \& Venter, I. (2010). Differences in self-monitoring between effective and ineffective leaders in the public sector: A South African study. The International Journal of Interdisciplinary Social Sciences, 5(2), 1-16.

Lee, C. S. (2018). Authentic leadership and organizational effectiveness: The roles of hope, grit, and growth mindset. International Journal of Pure and Applied Mathematics, 118(19), 383-401.

Leigh, J. (2014). Modelling suggests authentic leadership from managers influences structural empowerment, job satisfaction and self-rated performance among nurses. Evidence-Based Nursing, 17(2), 55-56.

Levesque-Côté, J., Fernet, C., Austin, S., \& Morin, A. J. S. (2018). New wine in a new bottle: Refining the assessment of authentic leadership using 
exploratory structural equation modeling (ESEM). Journal of Business and Psychology, 33(5), 611-628.

Lotka, A. J. (1926). The frequency distribution of scientific productivity. Journal of the Washington Academy of Sciences, 16(12), 317-323.

Luthans, F., \& Avolio, B. J. (2009). The "point"' of positive organizational behavior. Journal of Organizational Behavior, 30(2), 291-307.

McAuliffe, N., Bostain, N. S., \& Witchel, A. D. (2019). The relationship between authentic leadership, trust, and engagement in library personnel. Journal of Library Administration, 59(2), 129-148.

Miao, C., Humphrey, R. H., \& Qian, S. (2018). Emotional intelligence and authentic leadership: A meta-analysis. Leadership \& Organization Development Journal, 39(5), 679-690.

Moed, H. F. (2010). Measuring contextual citation impact of scientific journals. Journal of Informetrics, 4(3), 265-277.

Monzani, L., Braun, S., \& Van Dick, R. (2016). It takes two to tango: The interactive effect of authentic leadership and organizational identification on employee silence intentions. German Journal of Human Resource Management, 30(3-4), 246-266.

Monzani, L., Knoll, M., Giessner, S., Van Dick, R., \& Peiró, J. M. (2019). Between a rock and hard place: Combined effects of authentic leadership, organizational identification, and team prototypicality on managerial prohibitive voice. The Spanish Journal of Psychology, 22 (e2), 1-20.

Moriano, J. A., Molero, F., \& Mangin, J.-P. L. (2011). Liderazgo auténtico: Concepto y validación del cuestionario ALQ en España. Psicothema, 23 (2), 336-341.

Mubarak, F., \& Noor, A. (2018). Effect of authentic leadership on employee creativity in project-based organizations with the mediating roles of work engagement and psychological empowerment. Cogent Business \& Management, $5(1), 1-14$.

Nath, R., \& Jackson, W. M. (1991). Productivity of management information systems researchers: Does Lotka's law apply? Information Processing $\mathcal{E}$ Management, 27(2-3), 203-209.

Neider, L. L., \& Schriesheim, C. A. (2011). The Authentic Leadership Inventory (ALI): Development and empirical tests. The Leadership Quarterly, $22(6), 1146-1164$.

Northouse, P. G. (2016). Leadership: Theory and practice (7th ed.). Thousand Oaks: Sage. 
Oh, J., Cho, D., \& Lim, D. H. (2018). Authentic leadership and work engagement: The mediating effect of practicing core values. Leadership $\mathcal{E}$ Organization Development Journal, 39(1), 276-290.

Oluić-Vuković, V. (1997). Bradford's distribution: From the classical bibliometric "law" to the more general stochastic models. Journal of the American Society for Information Science, 48(9), 833-842.

Podsakoff, P. M., MacKenzie, S. B., Moorman, R., \& Fetter, R. (1990). Transformational leader behaviors and their effects on followers' trust in leader, satisfaction, and organizational citizenship behaviors. The Leadership Quarterly, 1(2), 107-142.

Raja, S., \& Agrawal, R. (2017). Cross-Cultural validation of the perceived brand greenness scale. In M. Stieler (Ed.). Creating marketing magic and innovative future marketing trends (pp. 1169-1183). Orlando: Springer.

Rautenbach, C., \& Rothmann, S. (2017). Psychometric validation of the Flourishing at Work Scale - Short Form (FWS-SF): Results and implications of a South African study. Journal of Psychology in Africa, 27 (4), 303-309.

Reed, L. L., Vidaver-Cohen, D., \& Colwell, S. R. (2011). A new scale to measure executive servant leadership: Development, analysis and implications for research. Journal of Business Ethics, 101 (3), 415-434.

Regan, S., Laschinger, H. K. S., \& Wong, C. A. (2016). The influence of empowerment, authentic leadership, and professional practice environments on nurses' perceived interprofessional collaboration. Journal of Nursing Management, 24(1), 54-61.

Rego, A., Sousa, F., Marques, C., \& Cunha, M. P. (2012). Authentic leadership promoting employees' psychological capital and creativity. Journal of Business Research, 65(3), 429-437.

Ryu, S. Y. (2015). Kunja leadership: Concept and nomological validity. Leadership \& Organization Development Journal, 36 (6), 744-764.

Schaufeli, W. B., \& Bakker, A. B. (2004). Job demands, job resources, and their relationship with burnout and engagement: A multi-sample study. Journal of Organizational Behavior, 25(3), 293-315.

Seligman, M. F. P. (2009). Felicidade autêntica: Usando a psicologia positiva para a realização permanente. Rio de Janeiro: Objetiva.

Shamir, B., \& Eilam, G. (2005). "What's your story?” A life-stories approach to authentic leadership development. The Leadership Quarterly, 16, 395-417. 
Spangenberg, H. H., \& Theron, C. C. (2002). Development of a uniquely South African leadership questionnaire. South African Journal of Psychology, 32(2), 9-25.

Stander, F. W., Beer, L. T. de, \& Stander, M. W. (2013). Authentic leadership as a source of optimism, trust in the organisation and work engagement in the public health care sector. SA Journal of Human Resource Management, 13(1), 1-12.

Steffens, N. K., Haslam, S. A., Reicher, S. D., Platow, M. J., Fransen, K., Yang, J., ... \& Boen, F. (2014). Leadership as social identity management: Introducing the Identity Leadership Inventory (ILI) to assess and validate a four-dimensional model. The Leadership Quarterly, 25(5), 1001-1024.

Strese, S., Gebhard, P., Feierabend, D., \& Brettel, M. (2018). Entrepreneurs' perceived exit performance: Conceptualization and scale development. Journal of Business Venturing, 33(3), 351-370.

Terry, R. W. (1993). Authentic leadership: Courage in action. Michigan: Wiley.

Toor, S.-U.-R., \& Ofori, G. (2009). Authenticity and its influence on psychological well-being and contingent self-esteem of leaders in Singapore construction sector. Construction Management and Economics, 27(3), 299-313.

Van Dierendonck, D. (2011). Servant leadership: A review and synthesis. Journal of Management, 37(4), 1228-1261.

Walumbwa, F. O., Avolio, B. J., Gardner, W. L., Wernsing, T., \& Peterson, S. J. (2008). Authentic leadership: Development and validation of a theorybased measure. Journal of Management, 34(1), 89-126.

Wiewiora, A., \& Kowalkiewicz, A. (2018). The role of authentic assessment in developing authentic leadership identity and competencies. Assessment $\&$ Evaluation in Higher Education, 44(3), 415-430.

Xiong, H.-B., \& Fang, P. (2014). Authentic leadership, collective efficacy, and group performance: An empirical study in China. Social Behavior and Personality, 42(6), 921-932.

Yagil, D., \& Medler-Liraz, H. (2014). Feel free, be yourself: Authentic leadership, emotional expression, and employee authenticity. Journal of Leadership $\mathcal{E}$ Organizational Studies, 21 (1), 59-70. 


\section{AUTHOR NOTES}

Barla L. T. Pioli, master from the Postgraduate Program in Administration (PPGA), Santa Catarina State University (Udesc); Simone G. Feuerschütte, Ph.D. from Production Engineering Department, Federal University of Santa Catarina (UFSC); Rafael Tezza, Ph.D. from the Production Engineering Department, Federal University of Santa Catarina (UFSC); Éverton L. P. L. Cancellier, Ph.D. from the Faculty of Economics, Administration and Accounting (FEA), University of São Paulo (USP).

Barla L. T. Pioli is now a doctorate student in Administration at the Postgraduate Program in Administration (PPGA) of Santa Catarina State University (Udesc); Simone G. Feuerschütte is now an associate professor at the Center for Administration and Socioeconomic Sciences of Santa Catarina State University (Udesc); Rafael Tezza is now an associate professor at the Center for Administration and Socioeconomic Sciences of Santa Catarina State University (Udesc); Éverton L. P. L. Cancellier is now an associate professor at the Center for Administration and Socioeconomic Sciences of Santa Catarina State University (Udesc).

Correspondence concerning this article should be addressed to Barla L. T. Pioli, Avenida Madre Benvenuta, 2007, Itacorubi, Florianópolis, Santa Catarina, Brasil, CEP 88035-901.

E-mail: barlatespioli2016@gmail.com

EDITORIAL BOARD

Editor-in-chief Gilberto Perez

Associated Editor

Sônia Maria Guedes Gondim

Technical Support

Vitória Batista Santos Silva

\section{EDITORIAL PRODUCTION}

Publishing Coordination

Jéssica Dametta

Layout Designer

Emap

Editorial Intern

Paula Di Sessa Vavlis

Graphic Designer

Libro 